\title{
Analysis of Asian herbs for the presence of aflatoxins using AFLACARD TOTAL for screening and immunoaffinity columns for quantification
}

\author{
Carol DonNELlY $^{* 1}$, Martin GALlaGHER ${ }^{* 1}$, Victoria JORDAN $^{* 1}$ and Hiroshi MoRITA ${ }^{* 2}$ \\ ${ }^{* 1}$ R-Biopharm Rhone Ltd (Block 10 Todd Campus, West of Scotland Science Park, Acre Road, Glasgow G20 0XA, UK) \\ Phone Number: +44 141945 2924, Fax Number: + 441419452925 \\ Email: carol@r-biopharmrhone.com \\ ${ }^{* 2}$ Azmax Co Ltd (1-10-7 Hatchoubori, Chuo-ku, Tokyo 104-0032 Japan)
}

\begin{abstract}
Summary
A method for the analysis of aflatoxins in a range of Asian herbs was developed using AFLACARD TOTAL, an antibody based card test after clean up with a solid phase column or with an immunoaffinity column. In this study ten types of herb were examined for aflatoxins $B_{1}, B_{2}, G_{1}$ and $\mathrm{G}_{2}$, using a number of different extraction methods and clean-up techniques prior to analysis with AFLACARD TOTAL. Results were confirmed using EASI-EXTRACT ${ }^{\mathbb{B}}$ Aflatoxin immunoaffinity columns in conjunction with HPLC. Extractions using $80 \%$ methanol were effective for simple herbs and required only clean-up with a solid phase syringe column, provided in the test kit to remove pigments. For more complex samples, a $75 \%$ acetonitrile solution was required in conjunction with an immunoaffinity column prior to analysis with AFLACARD TOTAL in order to improve extraction and sample clean up. In all cases, except a few species, the screening results achieved with the card were in agreement with the HPLC results and recoveries were above $70 \%$ for all herbs.
\end{abstract}

Key words : Aflatoxin, AFLACARD, Herbs, Immunoaffinity Column, HPLC

(Received: November 18, 2009, Accepted: February 6, 2010)

\section{Introduction}

Aflatoxins are toxic metabolites produced by the moulds Aspergillus flavus and Aspergillus parasiticus on crops following prolonged exposure to a high humidity or damage through stressful conditions such as drought ${ }^{1-3)}$. They are known carcinogens and can be found in a wide range of food samples including cereals, animal feed, nuts, nut products, dried fruits and spices ${ }^{1)}$. Aflatoxins have also been found in a wide range of medicinal herbs including peach kernel, zedoary, nelumbo seed and guarana. The use of plants in Asia as sources of food, poison and medicine dates back to prehistoric times, although the first official investigation of medicinal herbs only took place in the 8th century. In the 5th century, Chinese medicine had already been introduced to Japan via Korea. As an increased number of people are now using medicinal herbs as alternative therapies, there is now a focus on the safety of such products as they are regulated in a completely different manner to conventional medicines.

In the $\mathrm{EU}^{5)}$, there are regulations covering aflatoxin levels in food and feed which are currently set at 4 $\mu \mathrm{g} / \mathrm{kg}$ for total aflatoxin and $2 \mu \mathrm{g} / \mathrm{kg}$ for aflatoxin $\mathrm{B}_{1}$ in groundnuts, nuts, dried fruit and processed products. These levels also apply to cereals intended for human consumption. Levels for spices including those from 
the Capsicum and Piper species are $10 \mu \mathrm{g} / \mathrm{kg}$ for total aflatoxins and $5 \mu \mathrm{g} / \mathrm{kg}$ for aflatoxin $\mathrm{B}_{1}$. Though Japan has an official level and method for aflatoxin $\mathrm{B}_{1}$ in all foods including herbs, they are not for total aflatoxin, therefore total aflatoxin levels are being considered for these matrices. As a result there is an urgent requirement for suitable extraction methods and tests for screening and quantification. Since these commodities are often highly coloured, complex matrices and have a range of clinical and biological properties they are often difficult to analyze by standard analytical techniques. Immunoaffinity columns when used in conjunction with HPLC are ideal clean-up tools for concentrating mycotoxins in a variety of difficult commodities and have already been used successfully for analysis of spices, herbs, dried fruit and animal feed with good recoveries and accurate results ${ }^{4}$. For laboratories or companies who do not have access to analytical equipment there is however also the need for simple screening tests to detect aflatoxins in medicinal herbs. Many screening techniques such as ELISA's, fluorometry and lateral flow devices have been found to be unsuitable for analysing aflatoxins in medicinal herbs. This is mainly due to the color, pigments and components in these samples, which can often interfere with or mask test results. This study aims to examine various extraction methods for the analysis of a range of different types of herbs using both screening and quantitative tests.

\section{Materials and methods}

Chemicals and equipment All reagents were HPLC grade with acetonitrile and water purchased from Rathburn (Walkerburn) and methanol supplied by Fisher Scientific (Loughborough). Sodium hydroxide and Tween 20 were obtained from Sigma Aldrich Ltd (Dorset) and the TOTAL AFLATOXIN STANDARD SOLUTION and Phosphate buffered saline (PBS) were supplied by R-Biopharm Rhône Ltd (Glasgow). The TOTAL AFLATOXIN STANDARD SOLUTION $1 \mathrm{~mL}$ comprises with each $250 \mathrm{ng}$ of aflatoxin $\mathrm{B}_{1}, \mathrm{~B}_{2}, \mathrm{G}_{1}$ or $\mathrm{G}_{2}$, respectively.

EASI-EXTRACT ${ }^{\circledR}$ Aflatoxin immunoaffinity columns, AFLACARD TOTAL and associated reagents including solid phase syringe columns and sample diluent buffers were also supplied by R-Biopharm Rhône Ltd. AFLACARD TOTAL is a qualitative enzyme immunoassay performed on a card. The screening level of AFLACARD TOTAL can be adjusted as required depending on the extraction method and on the volume of sample extract applied to the card.

A Waring blender with 1 litre glass jar was used to blend the samples for the extraction of the aflatoxins. Whatman No.113 filter papers were used with $7.5 \mathrm{~cm}$ funnels for filtration. The HPLC system was purchased from Dionex (UK). The HPLC equipment consists of a system interface module, an HPLC pump, an injection valve, a precolumn, an analytical column, a Kobra Cell and a scanning fluorescence detector. The Kobra Cell was supplied by R-Biopharm Rhône Ltd.

Materials In order to carry out this study, 10 samples of Asian medicinal herbs were sent to R-Biopharm Rhône Ltd in Glasgow including peach kernel (Persicae semen: tônin), apricot kernel (Armeniacae semen: kyônin), zedoary (Zedoariae rhizoma: gajutsu), nelumbo seed (Nelumbis semen: renniku), guarana (Guarana semen), turmeric (Curcumae rhizoma: ukon), nutmeg (Myristicae semen: nikuzuku), citrus unshiu peel (Aurantii nobilis pericarpium: chinpi), bitter orange peel (Aurantii pericarpium : tôhi) and immature orange peel (Aurantii fructus immaturus: kijitsu).

Preparation of standards/Spiking for recovery To check the performance of the extraction methods, the 
samples were tested first using EASI-EXTRACT ${ }^{\circledR}$ Aflatoxin to ensure that they did not contain any aflatoxins, prior to spiking with aflatoxins. The samples were then spiked with $10 \mu \mathrm{g} / \mathrm{kg}$ or $20 \mu \mathrm{g} / \mathrm{kg}$ of total aflatoxin and retested using the chosen extraction procedure with AFLACARD TOTAL and EASI-EXTRACT ${ }^{\circledR}$ Aflatoxin.

A 4 point standard calibration curve for use with the EASI-EXTRACT ${ }^{\circledR}$ Aflatoxin column methods based on the assumption of $1 \mathrm{~g}$ equivalent being passed through the immunoaffinity column was prepared. The standard was prepared by taking $80 \mu \mathrm{L}$ at $1,000 \mathrm{ng} / \mathrm{mL}$ TOTAL AFLATOXIN STANDARD SOLUTION up to $2 \mathrm{~mL}$ methanol: water $(1: 1 \mathrm{v} / \mathrm{v})(=40 \mu \mathrm{g} / \mathrm{L}$ or $80 \mathrm{ng})$. Take $1 \mathrm{~mL}$ at $40 \mu \mathrm{g} / \mathrm{L}$ up to $2 \mathrm{~mL}$ methanol: water $(1: 1 \mathrm{v} / \mathrm{v})(=20 \mu \mathrm{g} / \mathrm{L}$ or $40 \mathrm{ng})$. Then, make $10 \mu \mathrm{g} / \mathrm{L}$ or $20 \mathrm{ng}$, and $5 \mu \mathrm{g} / \mathrm{L}$ or $10 \mathrm{ng}$ standard solutions by stepwise dilution with methanol: water $(1: 1 \mathrm{v} / \mathrm{v})$. The diluted standard solution of total aflatoxin was prepared freshly on the day of use with the $1,000 \mathrm{ng} / \mathrm{mL}$ total aflatoxin standard returned to the refrigerator at $4{ }^{\circ} \mathrm{C}$ where it was stable until the expiry date printed on the vial.

The following method was used for spiking samples at $10 \mu \mathrm{g} / \mathrm{kg}$ total aflatoxin concentration:

The sample was thoroughly blended and mixed prior to spiking. $50 \mathrm{~g}$ of the sample material was taken and placed in a suitable vessel. Then $0.5 \mathrm{~mL}$ of total AFLATOXIN STANDARD SOLUTION $(1,000 \mathrm{ng} / \mathrm{mL})$ was added to the sample resulting in a $10 \mathrm{ng} / \mathrm{g}$ spiked sample, it was then covered and left for $2-3 \mathrm{~h}$ at room temperature. The spiked sample can be stored at $4{ }^{\circ} \mathrm{C}$ in the dark overnight. Before analysis, the sample was mixed thoroughly and the assay performed using the EASI-EXTRACT ${ }^{\circledR}$ Aflatoxin immunoaffinity column as per the method. Finally $100 \mu \mathrm{L}$ of the final sample was injected onto the HPLC and the aflatoxin concentration recovered from the sample was calculated.

\section{Preparation of samples}

For peach kernel, apricot kernel, zedoary and nelumbo seed, $50 \mathrm{~g}$ of each material was weighed and extracted with $100 \mathrm{~mL}$ of methanol : water $(8: 2 \mathrm{v} / \mathrm{v})$. The sample was blended at high speed for $2 \mathrm{~min}$ before being filtered. The $\mathrm{pH}$ of the filtrate was adjusted to $7.4 \mathrm{using} 0.5 \mathrm{~mol} / \mathrm{L}$ sodium hydroxide.

For guarana, turmeric and nutmeg, $25 \mathrm{~g}$ of each material was weighed and extracted with $100 \mathrm{~mL}$ of acetonitrile: water $(75: 25 \mathrm{v} / \mathrm{v})$. The sample was blended and the $\mathrm{pH}$ was adjusted as the same manner described above.

For citrus unshiu, bitter orange peel and immature orange peel, $25 \mathrm{~g}$ of sample was weighed and extracted with $150 \mathrm{~mL}$ of acetonitrile:water $(75: 25 \mathrm{v} / \mathrm{v})$. The sample was blended and the $\mathrm{pH}$ was adjusted as the same manner described above.

\section{Analysis using AFLACARD TOTAL and EASI-EXTRACT ${ }^{\circledR}$ Aflatoxin immunoaffinity columns Peach Kernel, Apricot Kernel, Zedoary and Nelumbo Seed}

For screening at $4 \mu \mathrm{g} / \mathrm{kg}$ level using AFLACARD TOTAL, $1 \mathrm{~mL}$ of filtrate was added to $1 \mathrm{~mL}$ of $80 \%$ methanol: water $(\mathrm{v} / \mathrm{v})$ and then $1 \mathrm{~mL}$ of this solution was diluted with $3 \mathrm{~mL}$ of sample diluent buffer which was provided in the AFLACARD TOTAL kit. The solution was gently mixed and passed through a solid phase syringe column also provided in the kit with $500 \mu \mathrm{L}$ of resulting solution being added to the test port on the card and the assay performed as per the kit instructions.

For screening at $10 \mu \mathrm{g} / \mathrm{kg}$ level, $1 \mathrm{~mL}$ of filtrate was added to $4 \mathrm{~mL}$ of $80 \%$ methanol: water (v/v). Then the dilution, the column filtration and the application on the card were carried out with the same manner 
described above.

For the quantification and confirmation using EASI-EXTRACT ${ }^{\circledR}$ Aflatoxin with HPLC, $2 \mathrm{~mL}$ of filtered extract was diluted with $8 \mathrm{~mL}$ of PBS and passed through the immunoaffinity column according to the EASIEXTRACT $^{\circledR}$ Aflatoxin instructions for use and $100 \mu \mathrm{L}$ of diluted eluate was injected onto the HPLC.

\section{Guarana, Turmeric and Nutmeg}

For screening at $4 \mu \mathrm{g} / \mathrm{kg}$ level, $1 \mathrm{~mL}$ of filtrate was added to $29 \mathrm{~mL}$ of $10 \%$ Tween 20 and water. $30 \mathrm{~mL}$ of solution was passed through the EASI-EXTRACT ${ }^{\circledR}$ Aflatoxin column at a flow rate of $3 \mathrm{~mL}$ per minute. The column was washed with $20 \mathrm{~mL}$ of water. The toxin was eluted from the column using $1.5 \mathrm{~mL}$ of $100 \%$ methanol and collected in a suitable vial. $0.7 \mathrm{~mL}$ of the solution was added to $3 \mathrm{~mL}$ of the sample diluent buffer provided in the AFLACARD TOTAL kit. This was mixed gently and $2 \times 500 \mu \mathrm{L}$ of solution were applied to the test port on the card and the assay performed as per the kit instructions.

For quantification and confirmation, $1 \mathrm{~mL}$ of filtrate was then added to $29 \mathrm{~mL}$ of $10 \%$ Tween 20 and water. $30 \mathrm{~mL}$ of solution was passed through the EASI-EXTRACT ${ }^{\circledR}$ Aflatoxin immunoaffinity column at a flow rate of $3 \mathrm{~mL}$ per minute according to the EASI-EXTRACT ${ }^{\circledR}$ Aflatoxin instructions for use and $100 \mu \mathrm{L}$ of diluted eluate was injected onto the HPLC.

\section{Citrus Unshiu, Bitter Orange Peel and Immature Orange Peel}

For screening at $4 \mu \mathrm{g} / \mathrm{kg}$ level, the sample dilution and the immunoaffinity column chromatography were carried out in the same manner as the guarana, turmeric and nutmeg. The eluate was diluted with the sample diluent buffer as described above and was mixed gently, and then $2 \times 750 \mu \mathrm{L}$ of solution were applied to the test port on the card and the assay performed as per the kit instructions.

Quantification and confirmation were carried out in the same manner as the guarana, turmeric and nutmeg.

\section{Results and discussion}

For peach kernel, apricot kernel, zedoary and nelumbo seed, all of the cards showed reasonable results, as shown in Table 1. Significant natural contamination was recognized in peach kernel and zedoary samples. In these samples, the recovery was corrected with subtraction of the contamination. Zedoary and nelumbo seed gave low recovery $<60 \%$. It is possible that the lower recoveries obtained with these samples were caused by an uneven distribution of toxins.

For guarana, turmeric and nutmeg, the samples required a more rigorous extraction with $75 \%$ acetonitrile and more thorough clean up using an immunoaffinity column prior to application onto the AFLACARD TOTAL. The weight of sample was also reduced from $50 \mathrm{~g}$ to $25 \mathrm{~g}$ in this protocol to enable better extraction. All of the card results were consistent with results obtained using EASI-EXTRACT Aflatoxin immunoaffinity columns with HPLC, as shown in Table 2.

For citrus unshiu peel, bitter orange peel and immature orange peel the samples required a more rigorous extraction with $75 \%$ acetonitrile and the sample required greater clean up using an immunoaffinity column prior to application onto the AFLACARD. The weight of sample was also reduced from $50 \mathrm{~g}$ to $25 \mathrm{~g}$ and a greater volume of extraction solvent was used for the extraction of these samples, as they were more 
Table 1. Recovery after clean-up with EASI-EXTRACT Aflatoxin and results on the AFLACARD TOTAL (I)

\begin{tabular}{|c|c|c|c|c|}
\hline Sample & Spiked & $\begin{array}{c}\text { HPLC analysis after } \\
\text { using EASI-EXTRACT } \\
\text { Aflatoxin }\end{array}$ & $\begin{array}{c}\text { Recovery with using } \\
\text { EASI- EXTRACT } \\
\text { Aflatoxin }\end{array}$ & $\begin{array}{c}\text { AFLACARD TOTAL Result } \\
\text { at a } 4 \mu \mathrm{g} / \mathrm{kg} \text { or } 10 \mu \mathrm{g} / \mathrm{kg} \\
\text { screening level }\end{array}$ \\
\hline \multirow{2}{*}{ Peach kernel } & No & $3.87 \mu \mathrm{g} / \mathrm{kg}$ & N/A & Negative $(<10 \mu \mathrm{g} / \mathrm{kg})$ \\
\hline & $20 \mu \mathrm{g} / \mathrm{kg}$ & $18.45 \mu \mathrm{g} / \mathrm{kg}$ & $72.9 \%$ & Positive ( $\geqq 10 \mu \mathrm{g} / \mathrm{kg}$ ) \\
\hline \multirow{2}{*}{ Apricot kernel } & No & $<$ LOQ & N/A & Negative $(<4 \mu \mathrm{g} / \mathrm{kg})$ \\
\hline & $10 \mu \mathrm{g} / \mathrm{kg}$ & $7.95 \mu \mathrm{g} / \mathrm{kg}$ & $79.5 \%$ & Positive ( $\geqq 4 \mu \mathrm{g} / \mathrm{kg}$ ) \\
\hline \multirow{2}{*}{ Zedoary } & No & $6.24 \mu \mathrm{g} / \mathrm{kg}$ & N/A & Negative $(<10 \mu \mathrm{g} / \mathrm{kg})$ \\
\hline & $20 \mu \mathrm{g} / \mathrm{kg}$ & $16.7 \mu \mathrm{g} / \mathrm{kg}$ & $52.4 \%$ & Positive ( $\geqq 10 \mu \mathrm{g} / \mathrm{kg}$ ) \\
\hline \multirow{2}{*}{ Nelumbo seed } & No & $<\mathrm{LOQ}$ & N/A & Negative $(<4 \mu \mathrm{g} / \mathrm{kg})$ \\
\hline & $10 \mu \mathrm{g} / \mathrm{kg}$ & $5.70 \mu \mathrm{g} / \mathrm{kg}$ & $57.0 \%$ & Positive ( $\geqq 4 \mu \mathrm{g} / \mathrm{kg}$ ) \\
\hline
\end{tabular}

Aflatoxins were extracted with $100 \mathrm{~mL}$ of $80 \%$ methanol. The samples for the AFLACARD were not cleaned up with the EASI-EXTRACT Aflatoxin column.

N/A: not available. LOQ: Limit of quantification, $0.3 \mu \mathrm{g} / \mathrm{kg}$.

Table 2. Recovery after clean-up with EASI-EXTRACT Aflatoxin and results on the AFLACARD TOTAL (II)

\begin{tabular}{ccccc}
\hline \multirow{2}{*}{ Sample } & Spiked & $\begin{array}{c}\text { HPLC analysis after } \\
\text { using EASI-EXTRACT } \\
\text { Aflatoxin }\end{array}$ & $\begin{array}{c}\text { Recovery with using } \\
\text { EASI- EXTRACT } \\
\text { Aflatoxin }\end{array}$ & $\begin{array}{c}\text { AFLACARD TOTAL } \\
\text { Result at a } 4 \mu \mathrm{g} / \mathrm{kg} \\
\text { screening level }\end{array}$ \\
\hline \multirow{2}{*}{ Guarana } & No & $<\mathrm{LOQ}$ & N/A & Negative \\
\cline { 2 - 5 } & $10 \mu \mathrm{g} / \mathrm{kg}$ & $8.52 \mu \mathrm{g} / \mathrm{kg}$ & $85.2 \%$ & Positive \\
\cline { 2 - 5 } & No & $<\mathrm{LOQ}$ & N/A & Negative \\
\hline \multirow{2}{*}{ Nutmeg } & $20 \mu \mathrm{g} / \mathrm{kg}$ & $15.2 \mu \mathrm{g} / \mathrm{kg}$ & $76.0 \%$ & Positive \\
\cline { 2 - 5 } & No & $<\mathrm{LOQ}$ & $\mathrm{N} / \mathrm{A}$ & Negative \\
\hline
\end{tabular}

Aflatoxins were extracted with $100 \mathrm{~mL}$ of $75 \%$ acetonitrile. The samples for the AFLACARD were cleaned up with the EASI-EXTRACT Aflatoxin column.

LOQ: Limit of quantification, $0.3 \mu \mathrm{g} / \mathrm{kg}$.

N/A: not available.

Positive: above $4 \mu \mathrm{g} / \mathrm{kg}$ level,

Negative: below $4 \mu \mathrm{g} / \mathrm{kg}$ level.

absorbent than the previous matrices analysed. Cleaning up with the immunoaffinity column allowed recoveries of $>70 \%$ for most samples and the cards showed reasonable results, as shown in Table 3 .

\section{Conclusions}

Specific analytical methods were found to be suitable for the analysis of aflatoxin in a range of medicinal herbs. For peach kernel, apricot kernel, zedoary and nelumbo seed an $80 \%$ methanol extraction solvent was found to be the best and easiest extraction method requiring only a standard clean-up with a solid phase syringe column, provided in the kit to remove pigments. For more difficult samples such as guarana, turmeric, 
Table 3. Recovery after clean-up with EASI-EXTRACT Aflatoxin and results on the AFLACARD TOTAL (III)

\begin{tabular}{|c|c|c|c|c|}
\hline Sample & Spiked & $\begin{array}{c}\text { HPLC analysis after } \\
\text { using EASI-EXTRACT } \\
\text { Aflatoxin }\end{array}$ & $\begin{array}{c}\text { Recovery with using } \\
\text { EASI- EXTRACT } \\
\text { Aflatoxin }\end{array}$ & $\begin{array}{c}\text { AFLACARD TOTAL } \\
\text { Result at a } 4 \mu \mathrm{g} / \mathrm{kg} \\
\text { screening level }\end{array}$ \\
\hline \multirow{2}{*}{ Citrus unshiu peel } & No & $<\mathrm{LOQ}$ & N/A & Negative \\
\hline & $20 \mu \mathrm{g} / \mathrm{kg}$ & $17.46 \mu \mathrm{g} / \mathrm{kg}$ & $87.3 \%$ & Positive \\
\hline \multirow{2}{*}{ Bitter orange peel } & No & $<\mathrm{LOQ}$ & $\mathrm{N} / \mathrm{A}$ & Negative \\
\hline & $20 \mu \mathrm{g} / \mathrm{kg}$ & $23.04 \mu \mathrm{g} / \mathrm{kg}$ & $115 \%$ & Positive \\
\hline \multirow{2}{*}{ Immature orange peel } & No & $<\mathrm{LOQ}$ & $\mathrm{N} / \mathrm{A}$ & Negative \\
\hline & $20 \mu \mathrm{g} / \mathrm{kg}$ & $16.42 \mu \mathrm{g} / \mathrm{kg}$ & $81.9 \%$ & Positive \\
\hline
\end{tabular}

Aflatoxins were extracted with $150 \mathrm{~mL}$ of $75 \%$ acetonitrile. The samples for the AFLACARD were cleaned up with the EASIEXTRACT Aflatoxin column.

N/A: not available.

LOQ: Limit of quantification, $0.3 \mu \mathrm{g} / \mathrm{kg}$.

Positive: above $4 \mu \mathrm{g} / \mathrm{kg}$ level,

Negative: below $4 \mu \mathrm{g} / \mathrm{kg}$ level.

nutmeg, citrus unshiu peel, bitter orange peel and immature orange peel, extraction with $75 \%$ acetonitrile was required to improve extraction and increase recoveries. For these matrices the use of an EASIEXTRACT $^{\circledR}$ Aflatoxin immunoaffinity column was also included prior to screening with AFLACARD TOTAL to provide better clean-up and concentration of the aflatoxin from the sample for detection. In this study AFLACARD TOTAL enabled screening of medicinal herbs for aflatoxins at levels of $4 \mu \mathrm{g} / \mathrm{kg}$ and/or 10 $\mu \mathrm{g} / \mathrm{kg}$, while EASI-EXTRACT ${ }^{\circledR}$ Aflatoxin allowed recoveries of $>70 \%$ for most samples with the exception of zedoary and nelumbo seed, which gave recoveries of $<60 \%$.

In conclusion, AFLACARD TOTAL and EASI-EXTRACT ${ }^{\circledR}$ Aflatoxin immunoaffinity columns with HPLC were found to be suitable for screening and quantification of aflatoxins respectively in medicinal herbs.

\section{References}

1 ) Reif, K., Metzger, W.: J. Chromatogr. A, 692, 131-136 (1995)

2 ) Gomez-Catalan, J., Piqué, E., Falcó, G., Borrego, N., Rodamilans, M., Llobet, J.M.: Phytochem. Anal., 16, 196-204 (2005)

3 ) Tassaneeyakul, W., Razzazi-Fazeli, E., Porasuphatana, S., Bohm, J.: Mycopathologia, 158 , 239-244 (2004)

4 ) Stroka, J., Anklam, E., Jörissen, U., Gilbert, J.: J. AOAC Int., 83, 320-340 (2000)

5 ) Commission Regulation (EC) No. $1181 / 2006$ setting maximum levels for certain contaminants in foodstuffs 
生薬中のアフラトキシンの市販カード式 ELISA キットおよびイムノアフィニティーカラムによる スクリーニング法

Carol Donnelly, Martin Gallagher, Victoria JoRdan : R-Biopharm Rhône Ltd (Block 10 Todd Campus, West of Scotland Science Park, Acre Road, Glasgow G20 0XA, UK)

森田＼cjkstart裕：アッ゙マックス株式会社（104-0032＼cjkstart東京都中央区八丁堀 1-10-7）

生薬，香辛料中を污染するアフラトキシンの簡便なスクリーニングと定量のための前処理法の確立を目 的にして, 市販カード式 ELISA キット（アフラカード・トータル）, 固相カラム, イムノアフィニティー カラム（イージーエクストラクト・アフラトキシン）の使用法を検討した.

トウニン, キョウニン, ガジュツ, レンニクでは, 80 \% メタノールによる抽出, キットに備えつけの固 相カラムによる精製によって, カードで妥当な定性反応が示された. ガラナ, ウコン, ニクズク, チンピ, トゥヒ, キジッでは, 75 \%アセトニトリルによる抽出, イムノアフィニティーカラムによる精製によって, $70 \%$ 以上の高い回収率が得られ, カードで妥当な定性反応が示された.

キーワード : アフラトキシン, アフラカード, 生薬, イムノアフィニティーカラム, HPLC 